\title{
Resistant plasmid profile analysis of multidrug resistant Escherichia coli isolated from urinary tract infections in Abeokuta, Nigeria
}

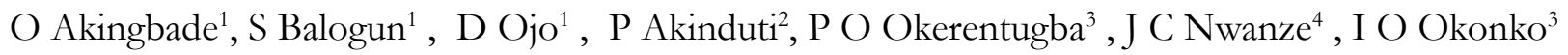

1. Department of Microbiology, Federal University of Agriculture, Abeokuta, Nigeria

2. Department of Medical Microbiology \& Parasitology, Olabisi Onabanjo University, Ago-Iwoye, Nigeria.

3. Medical Microbiology Unit, Department of Microbiology, University of Port Harcourt, East- West Road, P.M.B. 5323, Choba, Port Harcourt, Rivers State, Nigeria

4. Department of Pharmacology and Therapeutics, Igbinedion University, Okada, Edo State, Nigeria

\begin{abstract}
Background: Multi-drug resistant Escherichia coli has become a major threat and cause of many urinary tract infections (UTIs) in Abeokuta, Nigeria.

Objectives: This study was carried out to determine the resistant plasmids of multidrug resistant Escherichia coli isolated from (Urinary tract infections)UTIs in Abeokuta.

Methods: A total of 120 Escherichia coli isolates were obtained from urine samples collected from patients attending inpatient and outpatient clinics presenting UTI; with their biodata. Antibiotics susceptibility was performed and multi-drug resistant isolates were selected for plasmid profiling. Plasmids were extracted by the alkaline lysis method, electrophoresed on $0.8 \%$ agarose gel and profiled using a gel-photo documentation system gel.

Results: Escherichia coli isolates obtained shows high resistance to cloxacillin (92.5\%), amoxicillin (90.8\%), ampicillin (90.8\%), erythromycin (75.8\%), cotrimoxazole (70.0\%), streptomycin $(70.0 \%)$ and tetracycline $(68.3 \%)$ while $85.8 \%$ and $84.2 \%$ were susceptible to gentamycin and ceftazidime respectively. Sixteen Escherichia coli strains were observed to be resistant to more than two classes of antibiotics. The resistant plasmid DNA was detectable in $6(37.5 \%)$ of the 16 multidrug resistant Escherichia coli having single sized plasmids of the same weight 854bp and were all resistant to erythromycin, cefuroxime, cloxacillin, amoxicillin, ampicillin and cotrimoxazole.

Conclusion: This study has highlighted the emergence of multidrug resistant R-plasmids among Escherichia coli causing urinary tract infections in Abeokuta, Nigeria. There is a high level of resistance to many antimicrobials that are frequently used in Abeokuta, Nigeria.
\end{abstract}

Keywords: Escherichia coli, UTI, R-plasmid, multidrug resist

DOI: http://dx.doi.org/10.4314/ahs.v14i4.8

\section{Introduction}

Urinary tract infection is one of the significant illnesses that cause burden on national exchequer. Due to widespread and injudicious use of antibiotics at community level we are encountered more and more resistance pattern of micro-organisms to common antibiotics ${ }^{1}$. Urinary tract infections (UTIs) are among the most common infectious diseases of humans and a major cause of morbidity and mortality ${ }^{2-3}$. It is estimated

\section{Corresponding author:}

Iheanyi Omezuruike Okonko

Medical Microbiology Unit,

Department of Microbiology, University of

Port Harcourt,PMB 5323 Choba, East-West Road, Port

Harcourt, Rivers State, 500102 Nigeria;

E-mail:mac2finney@yahoo.com,

iheanyi.okonko@uniport.edu.ng;

Tel.: +2348035380891 that $40-50 \%$ of healthy adult women have experienced at least one UTI episode ${ }^{2-4}$.

UTI has become the most common hospital-acquired infection, accounting for as many as $35.0 \%$ of nosocomial infections, and it is the second most common cause of bacteraemia in hospitalized patients ${ }^{5}$. Previous reports have also suggested that UTI can occur in both males and females of any age, with bacterial counts as low as 100 colony forming units (CFU) per millimeter in urine $e^{5-10}$.

Occurrence of urinary pathogens varies among different age groups, sex, catheterization, hospitalization and previous exposure to antimicrobials ${ }^{11}$. Signs and symptoms of burning sensation during urination, frequent or intense urges to urinate, back or lower abdominal pain, fever or chills ${ }^{12}$, frequently characterize severe UTI. The leading causes of acute and uncompli- 
cated UTI in ambulatory patients have been reported to be due to Escherichia coli, Staphylococcus aureus, Proteus spp, Klebsiella spp and Pseudomonas aeruginosa $^{13-15}$. In Nigeria, E. coli, Proteus spp and Klebsiella spp have been isolated in $90.0 \%$ of UTI reported $\operatorname{cases}^{5,9,10,16-18}$.

Escherichia coli is the most common organism associated with asymptomatic bacteriuria $(\mathrm{ABU})^{19}$. In contrast to uropathogenic E. coli (UPEC), which causes symptomatic urinary tract infections (UTI), very little is known about the mechanisms by which these strains colonize the human urinary tract ${ }^{19}$. Escherichia coli is responsible for more than $80.0 \%$ of all UTIs and causes both ABU and symptomatic UTI ${ }^{19}$. The main factor pre-disposing to urinary tract infection has been attributed to poor personal hygiene and culture habit imposition ${ }^{15,20}$. Bacterial adhesion conferred by specific surface-associated adhesins is normally considered as a prerequisite for colonization of the urinary tract $t^{3}$.

Multiple drug resistance isolates causing UTI has serious implications for the empiric therapy against pathogenic isolates and for the possible co-selection of antimicrobial resistant mediated by multi drug resistant plasmids $^{21,22}$. E. coli from clinical isolates are known to harbour plasmids of different molecular sizes ${ }^{23}$. It has been widely reported that bacteria habour antibiotic resistant genes which can be horizontally transferred to other bacteria ${ }^{24}$.

According to Aibinu et al. ${ }^{25}$, E. coli is highly resistant to ampicillin, amoxicillin, tetracycline and trimethoprim sulfamethoxazole. The widespread occurence of drug resistant E. coli and other pathogens in our environment has necessitated the need for regular monitoring of antibiotics susceptibility trends to provide the basis for developing rational prescription programs, making policy decisions and assessing the effectiveness of both $^{26,27}$

In recent years, the application of molecular techniques for isolation and differentiation of bacterial isolates in hospitals have provided a set of powerful new tools that can augment both epidemiological investigations and patient treatment ${ }^{27-29}$. Therefore, this study was carried out to determine the resistant plasmids of multidrug resistant Escherichia coli isolated from Urinary tract infections in Abokuta, Nigeria.
Materials and methods

Collection of Samples: Clean-voided, mid-stream urine samples of about $20 \mathrm{ml}$ were collected from patients attending inpatient and outpatient Clinics in public health facilities in Abeokuta with their respective bio-data. The following signs and symptoms of UTI including frequency of micturation, retention of urine,

burning micturation, fever and chills were obtained.

Microbiological analysis: All urine samples were cultured within one hour of collection onto $\mathrm{MacCo}-$ nkey agar, Blood agar, Heated Blood Agar, and Eosin Methylene Blue Agar; and were incubated aerobically overnight at $37^{\circ} \mathrm{C}$. Samples that showed pure growth of isolate in a count of $\geq 105$ colony-forming units (CFU) per $\mathrm{ml}$ of urine after overnight incubation were considered to indicate significant bacteriuria ${ }^{30}$. Cultural characterisation was carried out on Escherichia coli using combination of colonial morphology, Gram stain characteristics, motility tests and pigmentation.

Biochemical test: oxidation-fermentation tests, cataase, oxidase activity tests, pyocyanin production, hydrolysis of arginine, nitrate production and growth on acetamide agar was carried out according to Cheesbrough $^{30}$

Antimicrobial sensitivity testing:Commercially available antimicrobial discs (Abtek Biological Ltd., UK) were used to determine the drug sensitivity and resistance pattern of the isolates. The 15 different antibiotics disc concentrations such as Gentamycin

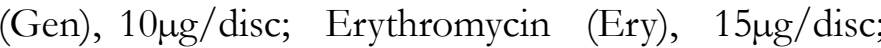

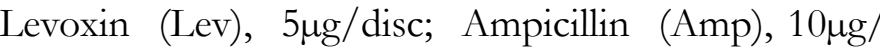
disc; Augmentin (Aug), 10ug/disc; Ceftriaxone (Cef)

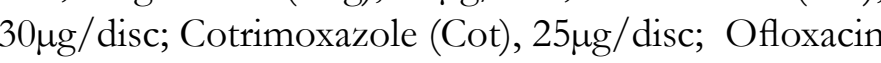

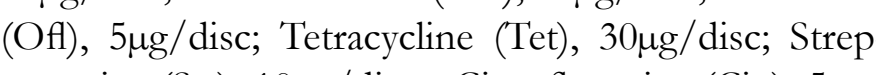

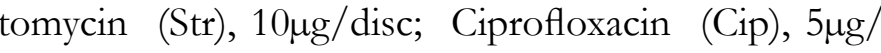

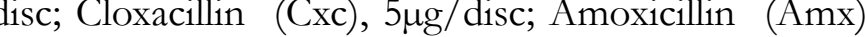

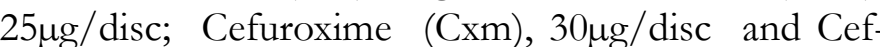

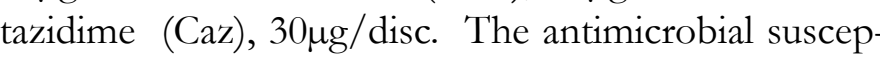
tibility test of each isolate was carried out as described by the Kirby - Bauer disc diffusion method ${ }^{31}$ using 0.5 Macfarland's standard turbidity and interpreted according to the National Committee for Clinical Laboratory Standards (NCCLS) ${ }^{32}$ to be recommendation and the control was ATCC $25922 \mathrm{E}$. coli strain. Plasmid isolation and profiling: Pure isolates of Escherichia coli strains were inoculated on Nutrient aga and incubated overnight. Resistant Plasmid DNA was extracted using alkaline lysis method (Zymogen, UK). Results

The extracted DNA was electrophoresied on a $0.8 \%$ Table 1 showed the antibiotic resistance and susceptiagarose gel stained with ethidium bromide. DNA mo- bility pattern of the 120 Escherichia coli isolates oblecular weight marker was loaded and electrophoresed tained from the urine samples. The result showed that in a horizontal tank at $100 \mathrm{~mA}$ at $30 \mathrm{v}$ for 30 minutes. Escherichia coli isolates had highest resistance $(92.5 \%)$ After electrophoresis, plasmid DNA bands were visu- to cloxacillin followed by amoxicillin (90.8\%), ampialized by fluorescence ultraviolet light transillumina- cillin $(90.8 \%)$, erythromycin $(75.8 \%)$, cotrimoxazole tor and analysed using a photo documentation system. $(70.0 \%)$, streptomycin $(70.0 \%)$ and tetracycline The molecular weights of the plasmid were calculated $(68.3 \%)$. E. coli isolates were most susceptible to genusing an online molecular weight calculator described tamycin an aminoglycoside (85.8\%), ceftazidime a third by Bikandi et al. ${ }^{34}$. Plasmid sizes were estimated by com- generation cephalosporin $(84.2 \%)$, levoxin a quinolone paring with previously characterized plasmids.

Plasmid Curing: The curing of the resistant plasmids of the clinical Escherichia coli isolates was done according to Vivyan et al..$^{35}$. (80.0\%), ceftriaxone another third generation cephalosporin $(76.7 \%)$, ciprofloxacin, ofloxacin (quinolone) $(72.5 \%)$ and $(60.8 \%)$ respectively.

Resistance of Escherichia coli strains to penicillins cloxacillin (92.5\%), amoxicillin (90.8\%) and ampicllin $(90.8 \%)]$ is too high. There is relatively high suscep-

Data analysis: Significance of the multi-drug resist- tibility of strains to ceftriaxone, ciprofloxacin and ant E. coli with their respectively plasmid weights ofloxacin. Very high susceptibility was regiswas determined by $\mathrm{X} 2$ at $\mathrm{p}<0.05$.

tered to gentamycin and ceftazidine. Detail analysis of

\begin{tabular}{llll}
\multicolumn{3}{l}{ Table 1. Antibiotic resistant and susceptibility pattern of the 120 } & Escherichia coli isolates \\
\hline Classes of Antibiotics & $\begin{array}{l}\text { Types of } \\
\text { Antibiotics }\end{array}$ & No. Resistant (\%) & No. Susceptible (\%) \\
& Streptomycin & $84(70.0)$ & $36(30.0)$ \\
& Gentamycin & $17(14.2)$ & $103(85.8)$ \\
Cephalosporin & Ceftazidime & $19(15.8)$ & $101(84.2)$ \\
& Ceftriaxone & $28(23.3)$ & $92(76.7)$ \\
Cotrimoxazole & Cefuroxime & $52(43.3)$ & $68(56.7)$ \\
Penicillin & Cotrimoxazole & $84(70.0)$ & $36(30)$ \\
& Ampicillin & $109(90.8)$ & $11(9.2)$ \\
& Amoxicillin & $109(90.8)$ & $11(9.2)$ \\
Quinolone & Augmentin & $53(44.2)$ & $67(55.8)$ \\
& Cloxacillin & $111(92.5)$ & $9(7.3)$ \\
& & $33(27.5)$ & $87(72.5)$ \\
& & & \\
Macrolide & Ofloxacin & $47(39.2)$ & $73(60.8)$ \\
Tetracycline & Levoxin & $24(20.0)$ & $96(80.0)$ \\
\hline
\end{tabular}

ntibiotic resistance profiles of strains show that a vast cherichia coli isolated from urine samples. The sixteen majority of the strains were resistant to more than one Escherichia coli isolates that were resistant to three or antibiotic $(72.0 \%)$. Sixteen strains $(13.3 \%)$ show resist- more classes of antibiotics in this study were E2, E6, ance to antibiotics from three and more classes and this E25, E27, E39, E46, E58, E67, E78, E81, E86, E90, define them as multidrug resistant. $\quad$ E99, E105, E113 and E117. Most of these strains were Table 2 shows antibiotic resistance profile of Es- resistant to cloxacillin, ampicillin, amoxicillin, streptomycin, erythromycin and tetracycline (Table 2). 
Table 2: Antibiotic profile of multi drug resistant Escherichia coli isolates isolated from patients with urinary tract infections

Isolates
E 2
E 6
E 25
E 27
E 39
E 46
E 58
E 67
E 78
E 81
E 86
E 90
E 99
E 105
E 113
E 117

\section{Resistant antibiotic}

Amp, Amx, Cxm, Cot, Cip, Cxc, Ery, Lev, Ofl, Str, Tet Amp, Amx, Aug, Cxm, Cip, Cxc, Ery, Ofl, Tet

Amp, Amx, Cot, Aug, Cef, Cxm, Gen, Lev, Ofl, Str, Lev

Amp, Aug, Cef, Cxm, Ery, Gen, Lev, Ofl, Str

Amp, Amx, Cot, Cef, Caz, Cxm,Cxc, Ery, Gen, Lev

Amp, Amx, Cot, Aug, Cxm, Cip, Cxc, Ery, Lev, Str, Tet

Amp, Amx, Cot, Cef, Caz, Cxm, Cxc, Ery, Ofl, Str, Tet

Amx, Aug, Cot, Cxm, Cxc, Ery, Ofl, Str, Tet, Lev

Amx, Aug, Cot, Cxm, Cip, Cxc, Ery, Ofl, Str, Tet, Lev

Amp, Amx, Cot, Cef, Cxm, Cxc, Ery, Gen, Ofl, Str, Tet

Amp, Amx, Cxm, Cip, Cxc, Ery, Ofl, Str, Tet, Lev

Amp, Amx, Cot, Aug, Cef, Cxm, Cip, Cxc, Ery, Gen

Amp, Amx, Cot, Cxm, Aug, Cef, Cxc, Ery, Gen, Lev,

Amp, Amx, Cot, Aug, Cef, Gen, Lev, Ofl, Str, Tet

Amp, Amx, Cot, Aug, Cef, Gen, Lev, Ofl, Str, Tet
Amp, Amx, Cef, Caz, Cxm, Cxc, Ery, Str, Tet, Lev

Amp, Amx, Cot, Aug, Cxm, Cxc, Ery, Ofl, Tet

$\overline{\mathrm{E}}=$ Escherichia coli

Figure 1 showed the Agarose gel electrophoretic analy- in 6(37.5\%) of the 16 selected multi-drug resistant Essis of the plasmids extracted from the multiple antibi- cherichia coli isolates. Ten of the isolates possessed no otic resistant isoltes. Iane $\mathrm{M}$, is the standart mo plasmid. The six isolates possessed single sized plasmids ar marker used (1000bp DNA ladder). The plasmid of the same weight 854bp. The six resistant plasmid analyses revealed that there were detectable plasmids bands were obtained from Escherichia coli isolates (E2, $\mathrm{E} 27, \mathrm{E} 58, \mathrm{E} 67, \mathrm{E} 90$ and E113).

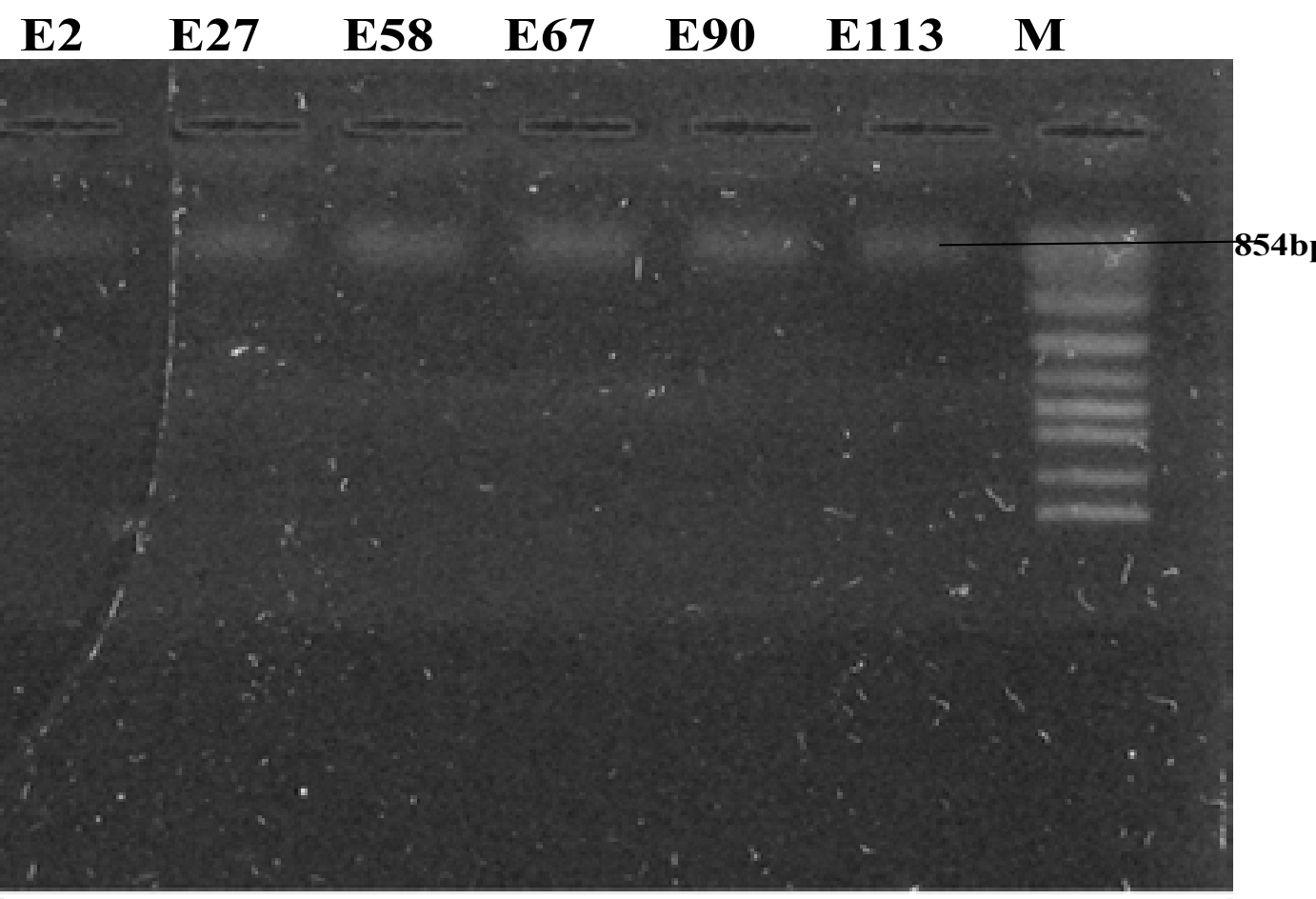

Figure 1: Agarose gel electrophoretic analysis of plasmids extracted from

multiple antibiotic resistant Escherichia coli isolates.
Escherichia coli has been reported as the most common cause of urinary tract infections $s^{10,36-37}$. The overall incidence of antibiotic resistant of Escherichia coli in this study was high.

Escherichia coli isolates had high resistant to cloxacillin, amoxicillin, ampicillin, erythromycin, cotrimoxazole, streptomycin and tetracycline. This high level of resistance of the E. coli to cloxacillin, amoxcillin and ampicillin was in agreement with the findings of Aibinu et al..$^{25}$, Daini and Adesemowo38, Ogbolu et al $^{39}$ and Stelling et a ${ }^{40}$. It has been reported that pathogenic isolates of $\mathrm{E}$. coli have relativity high potential for developing resistance ${ }^{41-42}$. Besides, amongst the enteric pathogens, resistant of E. coli was observed to be increasing, especially to first line, broad spectrum antibiotic. The high resistance of E. coli to numerous antimicrobial agents (antibiotics) observed in this present research may be due to indiscriminate and widespread use of these antibiotics in Abeokuta, Nigeria. Roos et $\mathrm{al}^{3,19}$ stated that drug resistance in pathogens is a serious medical problem because of very fast turn over and spread of mutant strains, insusceptible of medical treatment.

The resistance of urinary E. coli isolates to ampicillin in this study is consistent with reports from previous studies in Pakistan (78.4\%), showing high degree of resistance to E. coli ranging from $58.0 \%$ in 1989 to $74.0 \%$ in $2001^{4344}$. These resuls are congruent results reported by Aibinu et al. ${ }^{25}$ who found $100.0 \%$ resistance of E. coli isolates to ampicillin. Such multi drug resistance has serious implications for the empiric therapy of infections caused by E. coli ${ }^{21}$.

Resistant of E. coli from urinary tract infection to cotrimoxazole was $70.0 \%$ in this study and is in contrast to results obtained elsewhere. Cotrimoxazole resistance was approximately $30.0 \%$ in a study by Oteo et al. ${ }^{45}$ and similar to the $27.0 \%$ reported by Alos et al. ${ }^{46}$ in urinary tract infection isolates in Spain in 1993. Aiyegoro et al. ${ }^{47}$ reported that $66.7 \%$ of the pathogens were resistance to cotrimoxazole and that resistance of $\mathrm{E}$. coli to cotrimoxazole was $57.9 \%$. From the result of this study, it is obvious that cotrimoxazole is no longer effective against uropathogens. Previously, cotrimoxazole was used as the drug of choice for empirical treatment of UTI.

Escherichia coli isolates obtained from this research Six multi drug Escherichia coli possessed plasmids with were susceptible to gentamycin $(85.8 \%$ ), ceftazidime similar molecular weight of $854 \mathrm{bp}$ and were all resistant 
to erythromycin and cefuroxime. All the six isolates with the plasmids weight of $854 \mathrm{bp}$ were also resistance to cloxacillin, amoxicillin, ampicillin and cotrimoxazole. The emergence of R-plasmids in this study could be ascribed to the indiscriminate and widespread use of antibiotics caused by over- the- counter availability of antibiotics as well as the higher exposure of people to enteric flora in places with poor sanitation ${ }^{25,39,55,56}$. Clinical isolates of $\mathrm{E}$. coli which showed multiple drug resistance were also found to harbour plasmids with molecular sizes ranging from $2 \mathrm{~kb}$ to $6.5 \mathrm{~kb}$ and a maximum $26 \mathrm{~kb}$. This agrees favourably with previous studies. Umolu et al. ${ }^{27}$ reported that E. coli Isolates with high multi-drug resistance profiles were found to possess multiple plasmids with large sizes in the range of $6.557-23.130 \mathrm{~kb}$. This is also similar to what was observed by Smith et al. ${ }^{57}$ who reported that 47 of the E. coli isolated from animals in Lagos harboure detectble plasmids which ranged in sizes from $0.564 \mathrm{~kb}$ to $>23 \mathrm{~kb}$. Danbara et al..$^{23}$ also reported plasmids of sizes between $3.9 \mathrm{~kb}$ and $50 \mathrm{~kb}$ in E. coli strains isolated from Traveller's diarrhoea. Similarly, Todorova et al. ${ }^{5}$ showed that $92 \%$ of E. coli serotype 0164 strain possessed two small plasmids of molecular sizes $9.06 \mathrm{~kb}$ and $7.248 \mathrm{~kb}$

\section{Conclusion}

This study showed that Escherichia coli were most susceptible to gentamycin, ceftazidime Levoxin and ciprofloxacin. It also Escherichia coli used in this study all resistant to erythromycin, cefuroxime, cloxacillin, amoxicillin, ampicillin and cotrimoxazole. This study has also highlighted the emergence of multidrug resistant R-plasmids among Escherichia coli causing urinary tract infections in Abeokuta, Southwestern Nigeria. The uncontrolled use of antibiotics has contributed largely to this situation. Thus government should make considerable effort to establish an antibiotic policy for the country. Also the finding demonstrates an increasing incidence of urinary tract infections with multidrug resistant E. coli. Some of the isolates were harbouring plasmids. High resistance rates to penicillin were observed also among these strains. It is therefore recommended that extending mandatory surveillance to include urinary tract infections not only at hospitals but in the community to gain a bette understanding of plasmids mediated resistance $\mathrm{E}$ coli be carried out. Monitoring of plasmids mediated resistance and antimicrobial susceptibility testing was necessary to avoid treatment failure in patients with urinary tract infections.
Paryani JP, Memon, SR, Rajpar ZH, Shah A. Pattern and Sensitivity of Microorganisms

Causing Urinary Tract Infection at Teaching Hospital. JLUMHS, 2012; 11(02): 97-100

2. Roos V, Klemm P. Global gene expression profiling of the asymptomatic bacteriuria Escherichia coli strain 83972 in the human urinary tract. Infect Immun. 2006,74:3565-3575.

3. Roos V, Schembri MA, Ulett GC, Klemm P. Asymptomatic bacteriuria Escherichia colistrain 83972 carries mutations in the foc locus and is unable to express F1C fimbriae. Microbiology, 2006a, 152:1799-1806.

4. Soto SM, Jimenez de Anta MT, Vila J. Quinolones induce partial or total loss of pathogenicity island in uropathogenic Escherichia coli by SOS-dependent or -independent pathways, respectively. Antimicrob. Agents Chemother. 2006; 50(2):649-53.

5. Kolawole AS, Kolawole OM, Kandaki-Olukemi YT, Babatunde SK, Durowade KA, Kolawole CF. Prevalence of urinary tract infections (UTI) among patient attending Dalhatu Araf Specialist Hospital, Lafia, Nasarawa State, Nigeria. Int. J. Medicinal Med. Sci. 2009, 1(5):163-167

6. Azubuike JC, Nkeaniginieme KEO. Paediatrics and Applied Health in Nigeria 1999, pp. 236-239.

7. Omonigho SE, Obasi EE, Akukalia RN. In vitro

Resistance of Urinary Isolates of Escherichia coli and

Klebsiella species to Nalidixic Acid. Niger. J. Microbiol. 2001, 15(1):25-29

8. Ebie, M. Y., Kandakai-Olukemi, Y. T., Ayanbadejo, J. and Tanyigna, K.B. Urinary tract infections in a $\mathrm{Ni}$ gerian military hospital. Nigerian Journal of Microbiology, 2001, 15, 31-37.

Obiogbolu CH, IO Okonko, CO Anyamere, AO Adedeji, AO Akanbi, AA Ogun, J. Ejembi, TOC Faleye. Incidence of Urinary Tract Infections (UTIs) among Pregnant Women in Akwa Metropolis, Southeastern Nigeria. Scientific Research and Essay, 2009, 4(8):820-824 10. Okonko IO, Ijandipe LA, Ilusanya AO, DonbrayeEmmanuel OB, Ejembi J, Udeze AO, Egun OC, Fowotade A, Nkang AO. Incidence of Urinary Trac Infection (UTI) among Pregnant Women in Ibadan, South-Western Nigeria. African Journal of Biotechnology, 2009; 8(23):6649-6657

11. Moges, F., Genetu, A., and Mengstu, G. Antibiotic Sensitivity of Common Bacterial Pathogens in Urinary Tract Infections at Gondar Hospital, Ethiopia. East Afr. Med. J. 2002, 79:140-142.

2. National Kidney and Urologic Diseases Information Clearinghouse (NKUDIC). Fact sheet: Urinary
Tract Infections in Adults. NIH Publication No. 06-2097, Nat. Sci. 2006, Vol. 6 (In press).

2005

27. Umolu P. Idia Omigie O., Tatfeng Y, Omorogbe

13. Foxman B. urinary tract infection: Incidence and risk factors. Am J Pub Health. 1990; 80:331-333

14. Eva T, Bendt M, Jens K. Studies on betalactamases from Escherchia coli Isolated from urinary tract infection. AMPIS. 1990; 98: 345-52

15. Ehinmidu, J.O. Antibiotics susceptibility pattern of urine bacterial isolates in Zaria, Nigeria. Tropical Jour nal of Pharmacentical Research, 2003; 2 (2): 223-228 16. Olanipekun KA, Montefiore D. Bacterial infections, sensitivity patterns and chemotherapy among hospital patients in the tropics. Scand J Infect Dis. 1978; 10:295-302

17. Sever JL, Ellenberg JH, Edmonds D. Urinary Tract Infection During Pregnancy: Maternal an Paediatric Finding. In: Kass EH, Brumfitt W (eds). Infections of Urinary Tract. Chicago, USA: Cbicago Press, 1985 pp 19-21.

18. Obaseiki-Ebor EE. Trimethoprim Sulphamethiazole resistance in Escherichia coli and Klebsiella spp of urinary isolates. Afri J Med Sci. 1988; 17: 175-179.

19. Roos V, Ulett GC, Schembri MA, Klemm P. The asymptomatic bacteriuria Escherichia coli strain 83972 out-competes UPEC strains in human urine. Infect Immun. 2006b, 74:615-624.

20. Johnson JR. Urinary tract infection in women; Diagnosis and treatment. An Int Med.1989; 111: 109-17

21. Salm, D.F., C. Thornsbery, D.C. May field, M.E

Jones, J.A. Karlowsky. Antimicro. Agent chemother, 2001 $41,15-22$

22. Sherley, M., Gardon, D.M., Collingnon, P.J. Evolution of multi-resistance plasmids in Australia clinica isolates of Escherichia coli. Microbiology, 2004, 150: 1539 $-1546$.

23. Danbara, H., Komase, K Ivli, Y., Shinohawa, M Arita, H., Makino, A. and Yoshikawa, M. Analysis of the plasmids of Escherichia coli 0148:H28 from travellers with diarrhoea. Microbiol. Path. 1987, 3 (4): 269 - 278 24. Piddock, L.J.V. Clinically relevant chromosomally encoded multi drug resistance efflux pumps in bacteria. Clin. Microbiol. Rev., 2006, 19(2): 382-402. 25. Aibinu, I.E., Adenipekun, E.A., Odugbemi, T.O. Emergence of Quinolone Resistance amongst E. coli Strains Isolated from Clinical Infections in Some Lagos State Hospitals, in Nigeria. Nig. J. Health Biomed, Sci., 2004, 3: 73-78

26. Omigie, O., Enweani, I.B., Ohenhen, R.E., Umou, I.P. and BenEdo-Osagie, O. Bacteriological survey of wound infections in Benin City, Nigeria. Nig. Ann. ceptibility and Plasmid Profiles of Escherichia coli Isolates Obtained from Different Human Clinical Specimens in Lagos - Nigeria. The Journal of American Science, 2006; 2(4):70-75

8. Villari P, Iacuzio L, Torre I, Scarcella A. Molecula epidemiology as an effective tool in the surveillance of infection in neonatal intensive care unit. J. Infect., 1998, 37: 274- 281.

29. Gakuya, F., Kyule M. and Gathura, P. Antimicrobial susceptibility and plasmids from Escherichia coli isolates from rats East Afr. Med. J. 2001, 78: 518 - 522. 30. Cheesbrough, M. District laboratory practice in tropical countries. Cambridge University Press. 2004 pp. 357.

Bauer AW, Kirby MM, Sherris JC, Truck M. Antibiotic susceptibility testing by a standardized single disk method. American J. Clinical Pathology 1966; 45: 493-496. 32. National Committee for Clinical Laboratory Standards (NCCLS). Performance Standards for Antimicrobial Disk Susceptibility Testing, 10 Information Supplement Approved Standard, M100-S10, 2002, Wayne P. A. U.S.A.

33. Johnson, P. Plasmid analysis. In: Johnson A.P., Woodford, N. (eds.) Molecular Bacteriology Protocols and Clinical Applications. Humana Press Inc., Totowa, 1998, pp. 51- 62.

34. Bikandi, J., R. San Millán, A. Rementeria and J. Garaizar. In silico analysis of complete bacterial genomes: PCR AFLP-PCR and endonuclease restriction. Bioinformatics, 2004, 20: 798-799.

35. Vivyan E, Hedges RW, Datta N. Two modes of curing transmissible bacterial plasmids. J.Gen.Microiol 1972, 70:443-452

36. Andrade, S.S., Sader, H.S., Jones, R.N., Pereira, A.S., Pignatari, A.C. and Gales, A.C. Increased resistance to 1 rst-line agents among bacterial pathogens isolated from urinary tract infections in Latin America: time for local guidelines? Mem. Inst. Oswaldo Cruq, 2006 101:741-748.

37. Dash N, AL-Zarouni, M., Al-Kous N, Al- Shehhi F, Al-Najlar J, Senok A and Debadatta Panigrahi. Distribution and Resistance Trends of Community Associated Urinary Tract Pathogens in Sharjah, UAE. Mi crobiology Insights, 2008:1 41-45

38. Daini, O.A., Adesemowo, A. Antimicrobial Susceptibility Patterns and R-Plasmids of Clinical strains of Escherichia coli. Aust. J. Basic Appl. Sci., 2008, 2: 397400. 
39. Ogbolu, D.O., Daini, O.A., Ogunledun, A., Alli, A.O., Webber, M.A. High Levels of Multidrug Resistance in Clinical isolates of Gram-negative Pathogens from Nigeria. Int. J. Antimicrob. Agents, 2011, 37, 62-66. 40. Stelling, JM., Travers, K., Jones, R.N., Turner, P.J., O'Brien, T.F., and Levy, S.B. Integrating Escherichia coli antimicrobial susceptibility data from multiple surveillance programs Emerg. Iinfect. Dis., 2005, 11 (6): $873-882$.

41. Karlowsky, J.A., Jones, M.E., Draghi, D.C., Thornsbery, C., Sahm, D.F., Volturo, G.A. Prevalence of antimicrobial susceptibilities of bacteria isolated from blood cultures of hospitalized patients in the United States in 2002. Ann.. Clin. Microbiol. Antimicrob. 2004, 3 : 7. doi:10.1186/1476-0711-3-7

42. Nkang AO, Okonko IO, Mejeha OK, Adewale OG, Udeze AO, Fowotade A, Fajobi EA, Adedeji AO, Babalola ET. Assessment of antibiotics susceptibility profiles of some selected clinical isolates from laboratories in Nigeria. Journal of Microbiology and Antimicrobial, 2009, 1(2):019-026

43. Khan, S.W., Ahmed, A. Uropathogens and their Susceptibility Pattern: A Retrospective Analysis. J. Pak. Med. Assoc., 2001, 5 1:98-100.

44. Livermore, D.M., Brown, D.F. Detection of $\beta$-lactamase-mediated Resistance. J. Antimicrob. Chemother, 2001, 48:59-64.

45. Oteo, J., J. Campos and F. Baquero. Antibiotic resistance in 1962 invasive isolates of Escherichia coli in 27 Spanish hospitals participating in the European Antimicrobial Resistance Surveillance System. J. Antimicrob. Chemother, 2002. 50: 945-52.

46. Alos, J.I., J.L. Gómez-Garcés, I. García-Bermejo, J.J. García-Gómez, R. Gonzalez-Palacios and B. Padilla. The prevalence of Escherichia coli susceptibility to quinolone and other antibiotics in community-acquired bacteriurias in Madrid. Med. Clin., (Barc), 1993, 101:8790.

47. Aiyegoro OA, Igbinosa OO, Ogunmwonyi IN, Odjadjare EE, Igbinosa OE, Okoh AI. Incidence of urinary tract infections (UTI) among children and adolescents in Ile-Ife, Nigeria. Afr. J. Microbiol. Res., 2007, 013-019 48. Hassan, S.H. Sensitivity of Salmonella and Shigella to antibiotics and chemotherapeutic agents in Sudan. J. Trop. Med. Hyg., 1995, 88: 243 - 248.

49. Akinjogunla, O. J., Odeyemi, A. T. and Olasehinde,G. I. Epidemiological Studies of Urinary Tract Infection
(UTI) among Post-menopausal Women in Uyo Metropolis, South-South, Nigeria. Journal of American Science 2010; 6(12):1674-1681

50. Iqbal, M., I.K. Patel, Q. Ain,N. Barney,Q. Kiani,K.Z. Rabbani,G. Zaidi, B. Mehdi and S. H. Shah. Susceptibility Patterns of Escherichia coli: Prevalence of Multidrug- resistant Isolates and Extended Spectrum Beta-Lactamase Phenotype. JPMA, 2002, 52:407.

51. Farooqi BJ, Shareeq F, Rizvi QK, Qureshi HS, Ashfaq MK. Changing pattern of antimicrobial susceptibility of organisms causing community acquired urinary tract infections. J Pak Med Assoc. 2000; 50:369373.

52. Bolon, M.K., Wright, S.B., Gold, H.S., Cermeli, Y. The magnitude of the association between fluoroquinolone use and quinolone-resistant Escherichia coli and Klebsiella pneumoniae may be lower than previously reported. Antimicrob. Agents Chemother., 2004; 48: 1934 - 1940.

53. Oteo, J., Lazaro, E., de Abjo, F.j., Baquero, F., Campos, $J$ and Spanish members of EARSS. Antimicrobial ---resistant invasive Escherichia coli, Spain. Emerg. Infect. Dis. 2005, 11 (4): $546-553$

54. Alex, B., Goesseri, W., Schee, C.V., Margreet, C.V., Cornelissen, J., Hubert, E. Rapid emergence of Ofloxacin resistant Enterobacteriaeceae containing multiple Gentamicin resistant associated integron in a Dutch hospital. Emerg. Infect. Dis., 2001; 7 (5):862-871.

55. Daini, O. A., Ogbolu, D. O., Ogunledun, A. (2006). Plasmid Determined Resistance to Quinolones in Clinical isolates of Gram- negative Bacilli. Afr. J. MD. Med Sci., 2006, 35: 437-441.

56. Marquez, C., Lasbate, M., Raymondo, C., Fernandez, J., Gestol, A.M., Holley, M., Borthgaray, G., Stokes, H.W. Urinary Tract Infections in a South American Population: Dynamic Spread of Class 1 Integrons and Multidrug Resistance by Homologous and Site -Specific Recombination. J. Clin. Microbiol., 2008, 46: 3417-3425.

57. Smith, S.I., Aboaba, O.O., Odeigha, P., Shodipo, K., Adeyeye, J. A., Ibrahim, A., Adebiyi, T., Onibokun, H. and Odunukwe, N.N. Plasmid profile of Esherichia coli 0157:H7 from apparently healthy animals. Afr. J. Biotechnol., 2003, 2 (9): 322 - 324.

58. Todorova, K., Bratoera, M., and Danera, M. Characterization of enteroinvasive Escherichia coli serotype 0164 by means of plasmid analysis and virulence assay. J. Basic Microbiol., 1990, 30 (6): 451 - 454. 